\title{
Liquid whey protein concentrates as primary raw material for acid dairy gels
}

\author{
Marta Helena Fernandes HENRIQUES ${ }^{1,2 *}$ (D), David Manuel Gama Simões GOMES ${ }^{1,2}$, \\ Ana Raquel BORGES ${ }^{1}$, Carlos José Dias PEREIRA ${ }^{1,2}$
}

\begin{abstract}
The replacement of dehydrated products such as whey protein concentrates and isolates (WPC and WPI) by liquid whey protein concentrates (LWPC) obtained by ultrafiltration can be an excellent alternative for the production of innovative dairy products. Thus, the aim of this work is to study the gelation properties of LWPC as raw material for acid-induced dairy gels. Acid-induced gels were produced with non-defatted LWPC, with or without fortification with skimmed milk powder (SMP), by bacterial fermentation and by glucono- $\delta$-lactone (GDL) acidification. The fermented systems (yogurt type acid gels) produced weaker gel structures than the equivalent chemically acidified gels (dessert type acid gels). It was also observed that molecular rearrangement continues during cold storage and that fortification with SMP favoured gelation. Whey-based dairy gels obtained by fermentation or by glucono- $\delta$-lactone acidification presented viscoelastic behaviour, appealing functional and nutritional properties, and their utilization can effectively contribute to the reduction of waste.
\end{abstract}

Keywords: liquid whey protein concentrate; acid-induced gel; lactic acid bacteria; glucono- $\delta$-lactone; texture; rheology.

Practical Application: Direct use of LWPC for the production of functional acid dairy gels.

\section{Introduction}

The specific characteristics of whey proteins such as solubility, ability to form emulsions, foams and gels, favourable nutritional profile and diverse functional properties, make them an ideal ingredient in formulating several food products (Ha \& Zemel, 2003; Yadav et al., 2015; Smithers, 2015; Patel, 2015). Therefore, in recent years, whey has been widely used as an ingredient for healthy tailored dairy beverages, in most of the cases associated to fruits or other functional ingredients with prebiotic properties or fermented with probiotic bacteria (Pereira et al., 2015; Guimarães et al., 2018, 2019; Amaral et al., 2018). However, most studies are focused on the characteristics and properties of dehydrated whey protein products with high protein content (i.e. WPC or WPI) and little attention has been paid to the functionality of liquid whey protein concentrates (LWPC), used as such, in food formulations.

Traditionally, protein gelation has been achieved by heating, but some chemical processes form protein gels in a way analogous to heat-induction. In addition to heat, a chemical method, namely acidification, leads to modifications in protein-protein and protein-medium interactions inducing gelation (Totosaus et al., 2002). Acid-induced gels are common in the production of a variety of food products such as surimi, mayonnaise and gelatine-like desserts (Bryant \& McClements, 1998). This type of gelation involves heating the protein to form aggregates followed by reduction of the electrostatic repulsion between the aggregates by lowering the $\mathrm{pH}$ or by addition of salts that cause interactions which originate the formation of a network structure (Rabiey \& Britten, 2009;
Faria et al., 2013; Zhang et al., 2014). In this type of gelation the acidification process moves the $\mathrm{pH}$ towards the protein isoelectric point (pI), which can be achieved by applying a starter culture containing lactic acid bacteria or, chemically, by the addition of glucono- $\delta$-lactone (GDL). The pI's of whey proteins are 5.2 for $\beta-\mathrm{Lg}$, from $\mathrm{pH}=4.2$ to $\mathrm{pH}=4.5$ for $\alpha-\mathrm{La}$, from $\mathrm{pH}=4.7$ to $\mathrm{pH}=4.9$ for BSA and between $\mathrm{pH}=5.5$ and $\mathrm{pH}=6.8$ for Ig (Bryant \& McClements, 1998; Hong \& Creamer, 2002).

The gel structure and the dimensions of protein particles determine the properties of the gels, namely, the water holding capacity, permeability, texture, and appearance (Bryant \& McClements, 2000; Torres et al., 2016). The knowledge of the rheological properties of the system is fundamental since the physical attributes of foods, including viscosity, syneresis and colour are crucial aspects of quality and overall sensory acceptance on the part of consumers (Cavallieri et al., 2007; Lee \& Lucey, 2010).

This study intended to investigate the gelation properties of non-defatted (ND) liquid whey protein products (LWPC) obtained by ultrafiltration. Acid gels were produced by lactic acid fermentation (yogurt type gels) or acidification by GDL (dessert type gels) with or without the incorporation of skimmed milk powder (SMP). Interactions between proteins in the gel network structure were studied during storage by measuring the water retention capacity, texture and rheological behaviour of gels. 


\section{Materials and methods}

Bovine cheese whey was supplied by Queijaria Serqueijos SA (Rabaçal, Portugal). All the chemicals used were of analytical grade.

\subsection{LWPC manufacture}

Cheese whey from bovine origin, obtained immediately after production, was transported in metallic recipients $(50 \mathrm{~L})$ at ambient temperature to the pilot plant facilities at Escola Superior Agrária de Coimbra. In order to minimise product deterioration, the resting time between whey collection in the production plant and arriving at the pilot plant was less than 2 hours. Non-defatted (ND) liquid whey protein concentrate was produced according the method described by Henriques et al. (2017). Firstly, cheese fines were removed by filtration using a cloth filter, and whey was used directly for ultrafiltration (UF) using a pilot plant (Proquiga, Biotech S.A., La Coruña, Spain). Whey was concentrated in batch conditions with partial recirculation with a volumetric concentration factor (VCF) of 20. The ultrafiltration process was performed using an organic
UF membrane DSS (model 20K 3838-30) with a $5.5 \mathrm{~m}^{2}$ effective filtration area and a $20 \mathrm{kDa}$ cut-off (Iberlact, Madrid, Spain) at 40-45 ${ }^{\circ} \mathrm{C}$. The non-defatted LWPC was analysed and frozen at $-15^{\circ} \mathrm{C}$ before preparing the acid-induced gels.

\subsection{Gel preparation}

Two types of acid gels were produced: yogurt and dessert type gels (Figure 1). Both acid gels were prepared from non-defatted LWPC with or without the addition of skimmed milk powder (SMP). In all cases the LWPC was defrost under refrigeration $\left(8^{\circ} \mathrm{C}\right)$ and left overnight prior to manufacturing the acid gel.

For yogurt type acid gel production, the LWPC was first pasteurised at $90^{\circ} \mathrm{C}$ for $5 \mathrm{~min}$ (Tamime \& Robinson, 2007) and then cooled down to $60{ }^{\circ} \mathrm{C}$. The product was divided into two parts and SMP (Tecnilac, Viseu, Portugal) was added to one part, to obtain 5\% (by mass) incorporation in the final formulation. The remaining fraction was not enriched with SMP and, after cooling to $60^{\circ} \mathrm{C}$, both products were homogenised at $10^{7} \mathrm{~Pa}$ in a Rannie Model Blue Top homogenizer (Rannie, Copenhagen, Denmark). Before fermentation at $44{ }^{\circ} \mathrm{C}$ in an incubator chamber (Jenogand, model Y - 1000, Copenhagen, Denmark)

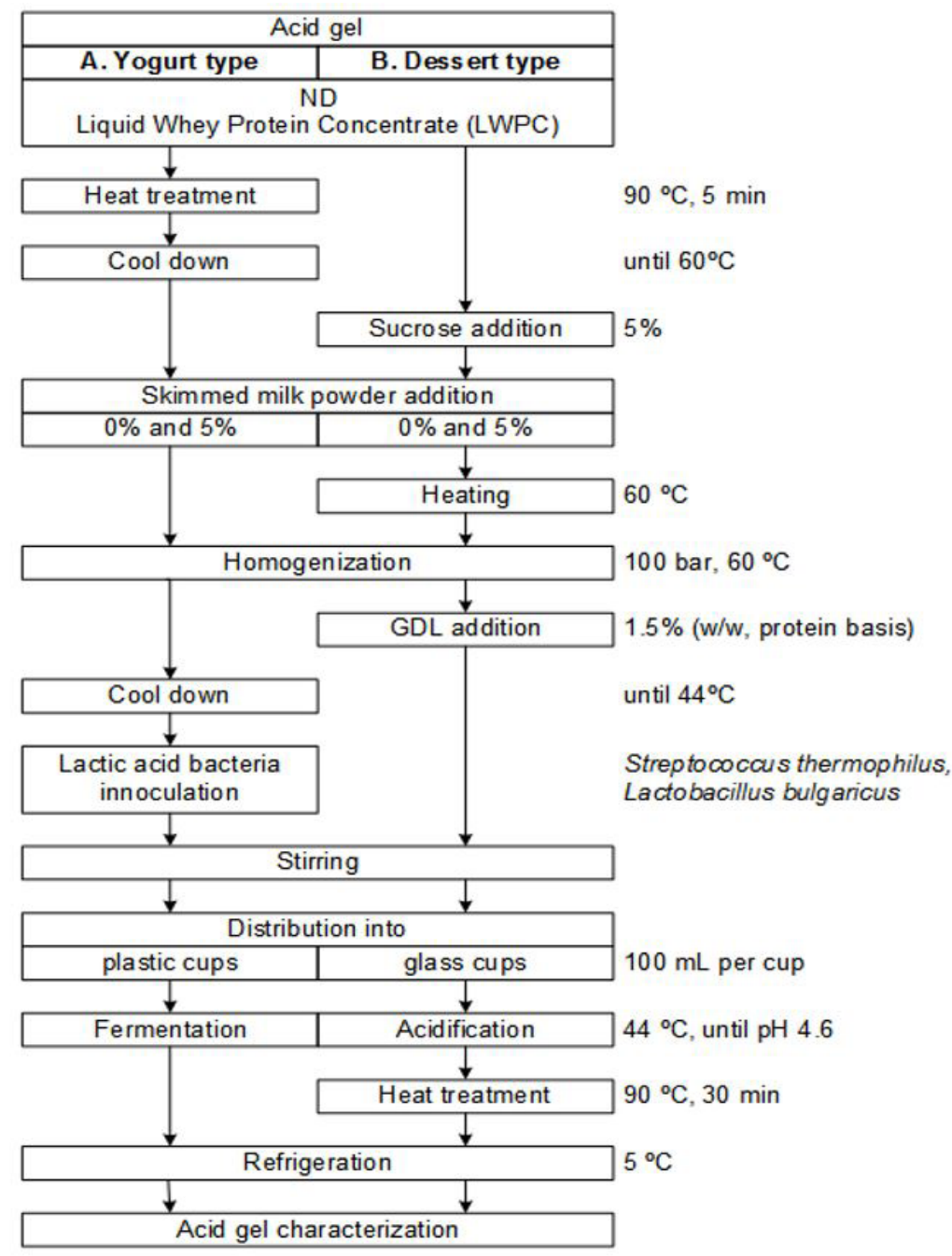

Figure 1. Process diagram of acid gels produced from non-defatted ND - LWPC: (A) yogurt type and (B) dessert type. 
the mixture was inoculated with a commercial mixed culture of Streptococcus thermophilus and Lactobacillus delbruekii ssp. bulgaricus Ezal YO-MIX 601 (Tecnilac, Viseu, Portugal), stirred and distributed into polystyrene cups ( $100 \mathrm{~mL}$ capacity). LWPC yogurt fermentation was monitored with a $\mathrm{pH}$ meter PHM61 Laboratory (A/S Copenhagen, Denmark) by assessing the $\mathrm{pH}$ until the products reached $\mathrm{pH}=4$.6. After one day of cold storage $\left(5^{\circ} \mathrm{C}\right)$ the biochemical composition of the yogurt type acid gels was determined. The physicochemical and rheological properties of the samples were evaluated on the first and last day of storage $\left(21^{\text {st }}\right.$ day) in order to investigate product stability.

In the case of the acid gel desserts (Figure 1), 5\% (by mass) sucrose (Sidul, Santa Iria da Azóia, Portugal) was added to the LWPC and two separate formulations were produced; one without SMP and one incorporating $5 \%$ (by mass). Both mixtures were heated to $60^{\circ} \mathrm{C}$ and homogenised at $10^{7} \mathrm{~Pa}$ in a Rannie Model Blue Top homogenizer (Rannie, Copenhagen, Denmark). GDL (Enzilab, Maia, Portugal) was then added to a level of 1.5\% (by mass, protein basis) and the mixture was gently stirred and distributed into $100 \mathrm{~mL}$ glass cups.

Acidification by GDL hydrolysis to gluconic acid took place under the same conditions as the yogurt type gel fermentation $\left(44{ }^{\circ} \mathrm{C}\right)$. After the gel $\mathrm{pH}$ reached 4.6 a heat treatment of $90^{\circ} \mathrm{C}$ was applied for $30 \mathrm{~min}$ in order to simultaneously promote pasteurisation of the product and increase the gel strength by protein thermal denaturation. Samples were then refrigerated in the same conditions as the yogurt type acid gels and their properties were evaluated using the same methods, on the $1^{\text {st }}$ and $21^{\text {st }}$ days after production.

\subsection{LWPC and gel compositional analyses}

After production, the non-defatted LWPC and the two types of acid gels were analysed in triplicate and quadruplicate, respectively, and characterised in terms of total solids, fat, protein, ash and lactose content. The $\mathrm{pH}$ of the samples was measured directly on the products with a pH meter PHM61 Laboratory (A/S Copenhagen, Denmark). Titratable acidity of the LWPC, expressed as a percentage of lactic acid, was determined according to the Portuguese Standard 470:1983 (Instituto Português da Qualidade, 1983), and for acid-induced gels the method used was NP 701:1982 (Instituto Português da Qualidade, 1982). In both cases, the titratable acidity of the samples, expressed as percentage of lactic acid, was determined by titration using $0,1 \mathrm{M} \mathrm{NaOH}$ (Fisher Chemical, supplied by VL2, Porto, Portugal) in an automatic titrator Metrohm 665 Dosimat (Metrohm AG, Herisau, Switzerland).

Total solids were determined according to the analytical official method 16.032 (Association of Official Analytical Chemists, 1980) by oven drying the samples at $102^{\circ} \mathrm{C}$ for 6 hours (Universal oven U15; Memmert GmbK+Co.KG, Schwabach, Germany) and mass weighing determined with an analytical balance (Sartorius, model TE 214S, Frankfurt, Germany). Total protein was estimated by multiplying the total nitrogen content of the samples by a factor of 6.38, being the nitrogen content determined using the Kjeldahl method according to International Organization for Standardization n. 8968-1 (International Organization for Standardization, 2001) using a digestion unit DK series and a distilling unit UDX both from Velp Scientifica, Usmate, Italy. Fat content of LWPC samples was determined by the adapted Gerber method (Instituto Português da Qualidade, 2002) and for the gels by the Gerber method used for yogurt (Instituto Português da Qualidade, 1987) using a Gerber K. Schneider \& CO AG centrifuge (Gerber Instruments AG, Effretikon, Switzerland). The ash content was determined by incinerating dried samples at $550{ }^{\circ} \mathrm{C}$ in an electric muffle furnace model LE 4/11/R6 (Nabertherm, Lilienthal, Germany) according to Association of Official Analytical Chemists (1995).

\subsection{Gel physicochemical analyses}

\section{Colour}

Colour was determined in triplicate on the surface of the gels located at the bottom of the plastic cups used to produce them. It was used a portable HP-2132 (Zhejiang Top Instruments Co, Ltd. Hangzhou, China) colorimeter equipped with a $\mathrm{C}$ illuminant in the CIEL $\mathrm{a}^{*} \mathrm{~b}^{*}$ colour system, calibrated with a white standard $\operatorname{dish}\left(L_{\text {std }}^{*}=97.03 ; a^{*}{ }_{\text {std }}=-0.67 ; b_{\text {std }}^{*}=5.57\right)$. The colour of the samples was expressed by the three individual coordinates of the CIEL ${ }^{\star} a^{\star} b^{\star}$ system.

\section{Water retention capacity}

Water retention capacity was determined using the method described by Gauche (2007). Triplicate, $20 \mathrm{~g}$, samples of LWPC gels were centrifuged at $350 \times g$ in a refrigerated centrifuge (Hettich, model Rotanta $460 \mathrm{R}$ ) during $10 \mathrm{~min}$ at $5{ }^{\circ} \mathrm{C}$. The supernatant was collected and weighed. WRC (percent) was calculated as the original mass of samples minus the supernatant mass divided by the original mass of sample multiplied by 100 .

\section{Textural analysis}

A Stable Micro Systems Texture analyser, TA.XT Express Enhanced model (Stable Micro Systems LTD., Godalming, UK), was used to carry out a textural analysis of the gels and the results were calculated using Specific Expression PC Software. A texture profile analysis (TPA) was run with a penetration distance of $5 \mathrm{~mm}$ at $1 \mathrm{~mm} / \mathrm{s}$ test speed, using an acrylic cylindrical probe with a diameter of $0.6 \mathrm{~mm}$ and a height of $3.5 \mathrm{~mm}$. The following parameters were quantified: hardness, adhesiveness, springiness, chewiness, cohesiveness, gumminess (the product of hardness and cohesiveness) and resilience (Phadungath, 2010).

\section{Rheological analysis}

Rheological properties of the gels were determined in triplicate at $15^{\circ} \mathrm{C}$, in a controlled stress rheometer (Rheostress 1, ThermoHaake) (Thermo Fisher Scientific Haake, Karlsruhe, Germany) in oscillatory mode. The measuring system consisted of a cone and plate geometry, $\mathrm{C} 35 / 1 \mathrm{Ti}$ ( $60 \mathrm{~mm}$ diameter and of $1^{\circ}$ angle). The gap between the cone and plate was maintained at $0.052 \mathrm{~mm}$. Stress sweep tests were conducted at a frequency of $1 \mathrm{~Hz}$ to investigate the rheological linear viscoelastic behaviour of gels. The rheological properties, elastic modulus $\left(G^{\prime}\right)$, viscous modulus $\left(G^{\prime \prime}\right)$, complex viscosity $\left(\eta^{*}\right)$ and the damping factor $(\tan \delta)$ of gels were evaluated in the range of $0.05-1.5 \mathrm{~Hz}$ at $3 \mathrm{~Pa}$. 


\section{Statistical analysis}

Statistical analysis of the data was carried out using the ANOVA package included in the Statistica 8 software. Means were compared using the Tukey HSD test. Differences were considered significant at ${ }^{*} \mathrm{p}<0.05$.

\section{Results and discussion}

Table 1 shows the gross chemical composition of non-defatted LWPC, and the acid gel biochemical composition for LWPC yogurts and desserts with (5\%) and without (0\%) incorporation of SMP.

Considering the composition of LWPC and its high protein content, it becomes evident that this material can be used as the main ingredient for the production of several dairy products. Naturally, its composition can be tailored according to the characteristics of the intended formulation (i.e. total solids, protein and fat contents can be varied by managing the volumetric concentration factor of the ultrafiltration process). Furthermore, the levels of lactose can be reduced by using diafiltration in order to produce lactose free products. Thus, the applied membrane technology can be easily adjusted according to the final formulation requirements. Considering the ease of operation, the production of LWPC can be applied in small and medium scale dairy plants, allowing for the development of differentiated and highly nutritious products, with low investments. Furthermore, the recovery of highly valued whey components for the production of innovative beverages plays an important role on the reduction of the environmental impact resulting from cheese plants operation, and contributes for the promotion of circular economy.

As expected, the products with SMP (Table 1) had significantly higher total solids than the unfortified products. The fat content did not vary in each product type $\left({ }^{*} \mathrm{p}>0.05\right)$ despite the addition of SMP. Although the protein content increased in products with 5\% (by mass) SMP, due to the incorporation of caseins, no significant differences $\left({ }^{\star} \mathrm{p}>0.05\right)$ were observed either in the formulations or the product types. Lactic desserts had significantly higher levels of other solids (mainly carbohydrates) due to the addition of sucrose in the formulation. Solvent evaporation during the longer heat treatment (30 $\mathrm{min})$ applied to desserts and the fermentation process in the case of yogurts, which converted lactose into lactic acid, may also have contributed to this difference.

The titratable acidity (Table 2) achieved for LWPC yogurt type acid gels (1.30-1.88\%) was higher than for the dessert gels

Table 1. Gross chemical composition of non-defatted LWPC, yogurt type and dessert type acid gels with $0 \%$ and $5 \%$ skimmed milk powder (SMP) incorporation.

\begin{tabular}{|c|c|c|c|c|c|}
\hline \multirow{2}{*}{$\begin{array}{l}\text { Composition } \\
\text { (\%, wet basis) }\end{array}$} & \multirow{2}{*}{ LWPC } & \multicolumn{2}{|c|}{ Yogurt type } & \multicolumn{2}{|c|}{ Dessert type } \\
\hline & & $0 \%$ & $5 \%$ & $0 \%$ & $5 \%$ \\
\hline Total solids & $21.50 \pm 0.08$ & $(22.13 \pm 0.98)^{\mathrm{a}}$ & $(26.10 \pm 0.15)^{b}$ & $(28.93 \pm 0.77)^{c}$ & $(32.08 \pm 0.07)^{\mathrm{d}}$ \\
\hline Fat & $7.10 \pm 0.35$ & $(5.50 \pm 0.49)^{\mathrm{b}}$ & $(4.63 \pm 0.41)^{\mathrm{ab}}$ & $(4.53 \pm 0.65)^{\mathrm{a}}$ & $(4.93 \pm 0.73)^{\mathrm{ab}}$ \\
\hline Protein & $8.60 \pm 0.01$ & $(7.17 \pm 0.68)^{\mathrm{a}}$ & $(8.94 \pm 1.33)^{\mathrm{a}}$ & $(6.29 \pm 2.43)^{\mathrm{a}}$ & $(8.88 \pm 1.44)^{\mathrm{a}}$ \\
\hline Ash & $0.85 \pm 0.01$ & $(0.96 \pm 0.04)^{\mathrm{a}}$ & $(1.63 \pm 0.34)^{\mathrm{a}}$ & $(1.38 \pm 0.10)^{\mathrm{a}}$ & $(3.51 \pm 0.19)^{\mathrm{b}}$ \\
\hline Other solids ${ }^{1}$ & $4.95 \pm 0.61$ & $(7.94 \pm 0.59)^{\mathrm{a}}$ & $(10.37 \pm 1.73)^{\mathrm{ab}}$ & $(16.17 \pm 1.03)^{\mathrm{c}}$ & $(14.99 \pm 1.68)^{b c}$ \\
\hline $\mathrm{pH}$ & $6.35 \pm 0.02$ & - & - & - & - \\
\hline $\mathrm{TA}^{2}$ & $0.29 \pm 0.01$ & - & - & - & - \\
\hline
\end{tabular}

Means with the same letter in the same row do not differ significantly ( $\mathrm{p}>0.05$ ); ${ }^{1}$ in which carbohydrates (such as lactose) are the major components (calculated by the difference between the total solids content and the sum of fat, protein and ash contents); ${ }^{2} \%$ lactic acid).

Table 2. Titratable acidity (TA), water retention capacity (WRC) and colour parameters $\left(\mathrm{L}^{*}, \mathrm{a}^{*}, \mathrm{~b}^{*}\right)$ of LWPC yogurts and desserts with $0 \%$ and $5 \%$ of SMP incorporation, during storage.

\begin{tabular}{|c|c|c|c|c|c|}
\hline \multirow{2}{*}{ Parameter } & \multirow{2}{*}{ t/days } & \multicolumn{2}{|c|}{ Yogurt type } & \multicolumn{2}{|c|}{ Dessert type } \\
\hline & & $0 \%$ & $5 \%$ & $0 \%$ & $5 \%$ \\
\hline \multirow[t]{2}{*}{$\mathrm{TA}^{1}$} & 1 & $(1.38 \pm 0.17)^{\mathrm{aA}}$ & $(1.46 \pm 0.18)^{\mathrm{aA}}$ & $(1.05 \pm 0.01)^{\mathrm{aA}}$ & $(1.58 \pm 0.02)^{\mathrm{bA}}$ \\
\hline & 21 & $(1.30 \pm 0.08)^{\mathrm{aA}}$ & $(1.88 \pm 0.11)^{\mathrm{bB}}$ & $(1.19 \pm 0.08)^{\mathrm{aB}}$ & $(1.21 \pm 0.14)^{\mathrm{aB}}$ \\
\hline $\mathrm{pH}$ & 21 & $(4.46 \pm 0.02)^{\mathrm{bA}}$ & $(4.39 \pm 0.01)^{\mathrm{aA}}$ & $(4.39 \pm 0.02)^{\mathrm{aB}}$ & $(4.64 \pm 0.04)^{\mathrm{bA}}$ \\
\hline WRC (\%) & 1 & $(65.74 \pm 1.62)^{\mathrm{bA}}$ & $(53.11 \pm 1.16)^{\mathrm{aA}}$ & $(70.49 \pm 4.58)^{\mathrm{aB}}$ & $(99.52 \pm 0.58)^{\mathrm{bA}}$ \\
\hline \multirow[t]{2}{*}{$\mathrm{L}^{*}$} & 1 & $(96.26 \pm 0.41)^{\mathrm{aA}}$ & $(96.98 \pm 0.17)^{\mathrm{aA}}$ & $(88.58 \pm 1.70)^{\mathrm{aA}}$ & $(92.16 \pm 3.61)^{\mathrm{aA}}$ \\
\hline & 21 & $(95.98 \pm 0.23)^{\mathrm{aA}}$ & $(97.65 \pm 0.42)^{\mathrm{bA}}$ & $(94.67 \pm 1.77)^{\mathrm{bA}}$ & $(82.52 \pm 6.83)^{\mathrm{aA}}$ \\
\hline \multirow[t]{2}{*}{$a^{*}$} & 1 & $(-0.45 \pm 0.24)^{\mathrm{aA}}$ & $(-0.30 \pm 0.22)^{\mathrm{aA}}$ & $(0.91 \pm 0.15)^{\mathrm{aA}}$ & $(0.13 \pm 0.35)^{\mathrm{aA}}$ \\
\hline & 21 & $(-0.59 \pm 0.41)^{\mathrm{aA}}$ & $(-0.73 \pm 0.48)^{\mathrm{aA}}$ & $(0.39 \pm 0.36)^{\mathrm{aA}}$ & $(1.86 \pm 1.11)^{\mathrm{aB}}$ \\
\hline$b^{*}$ & 1 & $(7.19 \pm 0.36)^{\mathrm{aA}}$ & $(7.08 \pm 0.16)^{\mathrm{aA}}$ & $(10.34 \pm 0.44)^{\mathrm{aA}}$ & $(11.08 \pm 0.70)^{\mathrm{aA}}$ \\
\hline
\end{tabular}

Means with the same letter in the same row do not differ significantly ( $\mathrm{p}>0.05)$. Lowercase letters represent differences between products $(0$ and $5 \%$ of SMP) and uppercase letters differences over storage ( $1^{\text {st }}$ and $21^{\text {st }}$ day); ${ }^{1}(\%$ lactic acid $)$. 
(1.05-1.58\%). This may indicate that acidification by bacterial fermentation is more effective than by GDL hydrolysis to gluconic acid. Higher acidity values were obtained in products based exclusively on LWPC or fortified with SMP in comparison to conventional yogurts or yogurts which incorporated LWPC previously produced by us (Henriques et al., 2011; Henriques et al., 2012). This was expected to some extent, since the LWPC products used as a raw material for yogurt production have higher acidity levels ( $\approx 0.52 \%$ lactic acid) than the milk used in the production of conventional yogurts $(\approx 0.185 \%$ lactic acid for bovine milk).

Some authors have stated that protein composition is one of the most significant factors influencing the duration of yogurt bacterial fermentation (Puvanenthiran et al., 2002). They have noted that by increasing the whey protein/casein fraction the time of bacterial fermentation also increases as a result of the higher buffering capacity of the whey proteins. Our results (Table 2) concur with this, since the yogurts with higher amounts of whey proteins ( $0 \%$ of SMP) showed higher $\mathrm{pH}$ values for the same fermentation time. A significant decrease $(\mathrm{p}<0.05)$ in $\mathrm{pH}$ was also observed during storage for both types of yogurts, which may indicate that fermentation continues during storage. A distinctive type of behaviour was found in desserts. Higher $\mathrm{pH}$ values were observed in products incorporating SMP, which corroborate the results published by (Lucey et al., 1999) for acid gels produced by GDL. This divergence in the $\mathrm{pH}$ of acid gels produced by bacterial fermentation or by GDL acidification may be due to the moment at which the heat treatment was performed during the acid gels production. In the case of yogurts, whey protein denaturation occurs during the pasteurisation $\left(90^{\circ} \mathrm{C}, 5 \mathrm{~min}\right)$ of LWPC, prior to the addition of SMP and fermentation. However, in desserts produced chemically by GDL, acid-induced gelation occurs when the whey proteins are still in their native form, since the heat treatment $\left(90^{\circ} \mathrm{C}, 30 \mathrm{~min}\right)$ is only applied at the end of the production process (Figure 1). It was also observed that during storage the $\mathrm{pH}$ of desserts hardly varied.

Table 2 also shows the water retention capacity (WRC) of the systems studied. Specific WRC behaviour can be observed in the LWPC acid gels according to their nature (yogurt or dessert), SMP incorporation and storage time. The desserts showed a higher water retention capacity $(64.12-100 \%)$ than yogurts (53.11-65.74\%), which can be attributed firstly to their higher total solids content (Table 1) and also to the heat treatment performed after acidification. In this case, protein denaturation under acidic conditions significantly improved this property. In yogurts, the acidification occurs progressively during fermentation but after whey protein denaturation. Cavallieri et al. (2007) distinguished two kinds of interaction in the protein network of the acid gels: interaction between part of the protein and water by hydrogen bonding, and interaction between the majority of proteins by electrostatic and hydrophobic interactions or even by hydrogen bonding. It was also observed that yogurts fortified with 5\% SMP had a lower WRC. This may be due to the fact that the presence of native caseins (that have not been denatured, as it occurred with whey proteins) may create some discontinuity in the protein network by reducing the capacity to retain water. Several authors (Puvanenthiran et al., 2002; Lucey et al., 1999; Sodini et al., 2002, 2004; Amatayakul et al., 2006) mentioned that higher amounts of whey proteins in yogurt lead to a higher level of protein interaction and to the formation of a compact gel structure that is responsible for reducing syneresis (Bhullar et al., 2002; Aziznia et al., 2008). In the case of desserts with 5\% SMP, in which whey protein and casein denaturation occurred simultaneously, the WRC was improved in comparison to desserts with no caseins ( $0 \%$ of SMP). This demonstrates that whey proteins and caseins are able to interact when denatured simultaneously, and this in turn favours the formation of bridges leading to a narrow-pore mixed casein/whey protein network. As the pore size decreases, lower syneresis values are obtained (And \& Guo, 2006).

With regard to colour (Table 2), higher luminosity values $\left(L^{*}\right)$ were found for yogurt type gels, which are in the range of 95.98-97.65. The slightly darker colour for desserts (82.52-94.67) was probably due to the intense heat treatment performed in this product $\left(90^{\circ} \mathrm{C}, 30 \mathrm{~min}\right.$ ) and to the higher solids content resulting from sucrose addition and solvent evaporation. The colour coordinate $a^{*}$ was the most affected amongst the products. It changed from negative values (green direction) in the case of yogurts to positive values (red direction) in the case of desserts. During heating, the Maillard reactions lead to the development of a light brown colour that explains these results, as well as the increase in the $b^{\star}$ coordinate (yellow direction). The colour parameters of yogurt type acid gels are in the same range of magnitude as the values mentioned by Martín-Diana et al. (2004) and Vargas et al. (2008), and in some cases have higher luminosity values than those reported by Sanmartín et al. (2015). As previously mentioned, the intense heat treatment used in the case of desserts particularly affected their chromatic coordinates.

The texture parameters of acid gels are presented in Table 3. With regard to hardness, it was observed that desserts present higher values than yogurts, and the incorporation of SMP in the formulation also contributes to this. These results concur with the higher water retention observed for desserts with 5\% SMP (Table 2), indicating that harder gel structures have the ability to prevent syneresis more efficiently.

Bell (1995) also found that bovine and caprine fermented systems produce weaker gel structures then their equivalent chemically acidified gels (GDL acidification). Yogurts with 5\% SMP showed lower hardness values after production ( $1^{\text {st }}$ day), although during storage they became harder, meaning that protein polymerization continued under refrigeration conditions.

The fortified desserts showed the highest values for adhesiveness, chewiness and gumminess. No differences ( $p>0.05)$ were observed in springiness and cohesiveness, either between products (SMP incorporation) or during storage. The values for springiness (near to the unit) indicate the viscoelastic behaviour of the LWPC acid gels.

Figure 2 represents the elastic and viscous modulus ( $G$ ' and $G^{\prime \prime}$ ) of acid-induced gels (yogurts and desserts) as a function of incorporating SMP, storage time and frequency $(\mathrm{rad} / \mathrm{s})$. Figure 3 shows their complex viscosity $\left(\eta^{\star}\right)$.

It was observed that in all cases the elastic modulus $\left(G^{\prime}\right)$ is higher than the viscous modulus $\left(G^{\prime \prime}\right)$ demonstrating the gel structure and the viscoelastic behaviour of both products. An increase in $G$ ' and $G$ " was observed over time. This indicates that 
Table 3. Texture parameters: hardness, adhesiveness, springiness, chewiness, gumminess cohesiveness and resilience of LWPC yogurts and desserts with $0 \%$ and $5 \%$ of SMP incorporation, during storage.

\begin{tabular}{|c|c|c|c|c|c|}
\hline \multirow{2}{*}{ Parameter } & \multirow{2}{*}{ t/day } & \multicolumn{2}{|c|}{ Yogurt type } & \multicolumn{2}{|c|}{ Dessert type } \\
\hline & & $0 \%$ & $5 \%$ & $0 \%$ & $5 \%$ \\
\hline \multirow[t]{2}{*}{ Hardness/N } & 1 & $(0.10 \pm 0.00)^{\mathrm{aA}}$ & $(0.09 \pm 0.01)^{\mathrm{aA}}$ & $(0.11 \pm 0.02)^{\mathrm{aA}}$ & $(0.59 \pm 0.12)^{\mathrm{bA}}$ \\
\hline & 21 & $(0.11 \pm 0.00)^{\mathrm{aA}}$ & $(0.15 \pm 0.01)^{\mathrm{bB}}$ & $(0.18 \pm 0.02)^{\mathrm{aA}}$ & $(0.44 \pm 0.16)^{\mathrm{bA}}$ \\
\hline \multirow[t]{2}{*}{ Adhesiveness/N.s } & 1 & $(0.31 \pm 0.04)^{\mathrm{aA}}$ & $(-0.13 \pm 0.02)^{\mathrm{bB}}$ & $(-0.30 \pm 0.12)^{\mathrm{bA}}$ & $(-2.42 \pm 0.52)^{\mathrm{aA}}$ \\
\hline & 21 & $(-0.35 \pm 0.03)^{\mathrm{aA}}$ & $(-0.33 \pm 0.04)^{\mathrm{aA}}$ & $(-0.63 \pm 0.24)^{\mathrm{aA}}$ & $(-1.35 \pm 0.71)^{\mathrm{aA}}$ \\
\hline \multirow[t]{2}{*}{ Springiness } & 1 & $(0.96 \pm 0.01)^{\mathrm{aA}}$ & $(0.97 \pm 0.01)^{\mathrm{aA}}$ & $(0.97 \pm 0.02)^{\mathrm{aA}}$ & $(0.97 \pm 0.01)^{\mathrm{aA}}$ \\
\hline & 21 & $(0.96 \pm 0.01)^{\mathrm{aA}}$ & $(0.97 \pm 0.00)^{\mathrm{aA}}$ & $(0.95 \pm 0.02)^{\mathrm{aA}}$ & $(0.97 \pm 0.03)^{\mathrm{aA}}$ \\
\hline \multirow[t]{2}{*}{ Chewiness/N.mm } & 1 & $(6.52 \pm 0.19)^{\mathrm{aA}}$ & $(6.14 \pm 0.21)^{\mathrm{aA}}$ & $(6.78 \pm 1.13)^{\mathrm{aA}}$ & $(35.23 \pm 6.79)^{\mathrm{bA}}$ \\
\hline & 21 & $(7.69 \pm 0.10)^{\mathrm{aB}}$ & $(10.55 \pm 0.44)^{\mathrm{bB}}$ & $(10.23 \pm 1.47)^{\mathrm{aA}}$ & $(26.76 \pm 10.58)^{\mathrm{aA}}$ \\
\hline \multirow[t]{2}{*}{ Gumminess/N } & 1 & $(6.82 \pm 0.18)^{\mathrm{aA}}$ & $(6.33 \pm 0.23)^{\mathrm{aA}}$ & $(7.01 \pm 1.23)^{\mathrm{aA}}$ & $(36.29 \pm 6.92)^{\mathrm{bA}}$ \\
\hline & 21 & $(8.01 \pm 0.16)^{\mathrm{aB}}$ & $(10.91 \pm 0.49)^{\mathrm{bB}}$ & $(10.78 \pm 1.53)^{\mathrm{aA}}$ & $(27.45 \pm 10.13)^{\mathrm{bA}}$ \\
\hline \multirow[t]{2}{*}{ Cohesiveness } & 1 & $(0.70 \pm 0.01)^{\mathrm{aA}}$ & $(0.71 \pm 0.03)^{\mathrm{aA}}$ & $(0.62 \pm 0.04)^{\mathrm{aA}}$ & $(0.60 \pm 0.03)^{\mathrm{aA}}$ \\
\hline & 21 & $(0.69 \pm 0.03)^{\mathrm{aA}}$ & $(0.72 \pm 0.05)^{\mathrm{aA}}$ & $(0.57 \pm 0.02)^{\mathrm{aA}}$ & $(0.60 \pm 0.03)^{\mathrm{aA}}$ \\
\hline \multirow[t]{2}{*}{ Resilience } & 1 & $(0.05 \pm 0.00)^{\mathrm{aA}}$ & $(0.09 \pm 0.01)^{\mathrm{bB}}$ & $(0.04 \pm 0.01)^{\mathrm{aA}}$ & $(0.02 \pm 0.01)^{\mathrm{aA}}$ \\
\hline & 21 & $(0.05 \pm 0.00)^{\mathrm{aA}}$ & $(0.05 \pm 0.01)^{\mathrm{aA}}$ & $(0.02 \pm 0.01)^{\mathrm{aA}}$ & $(0.03 \pm 0.01)^{\mathrm{aA}}$ \\
\hline
\end{tabular}

Means without the same letter differ statistically at $\mathrm{p}<0.05$. Lowercase letters represent differences between products $(0$ and $5 \%$ of SMP) and uppercase letters differences over storage $\left(1^{\text {st }}\right.$ and $21^{\text {th }}$ days); $\mathrm{N}$ means Newton units.

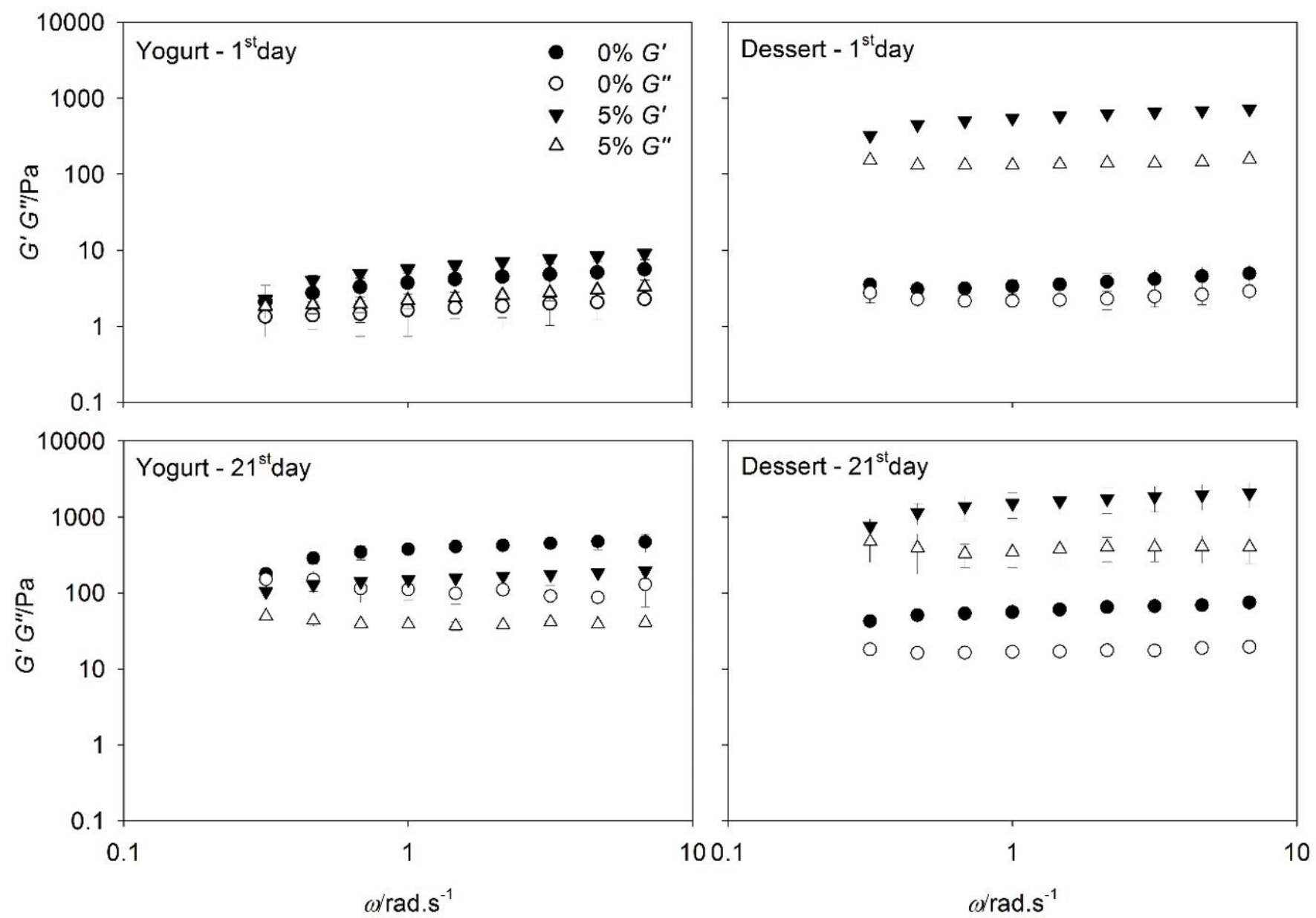

Figure 2. Elastic modulus (G') of LWPC yogurts and desserts with $0 \%(\bullet)$ and $5 \%(\boldsymbol{\nabla})$ of SMP incorporation; viscous modulus (G") of LWPC yogurts and desserts with $0 \%(\mathrm{o})$ and $5 \%(\Delta)$ of SMP incorporation, during storage. 


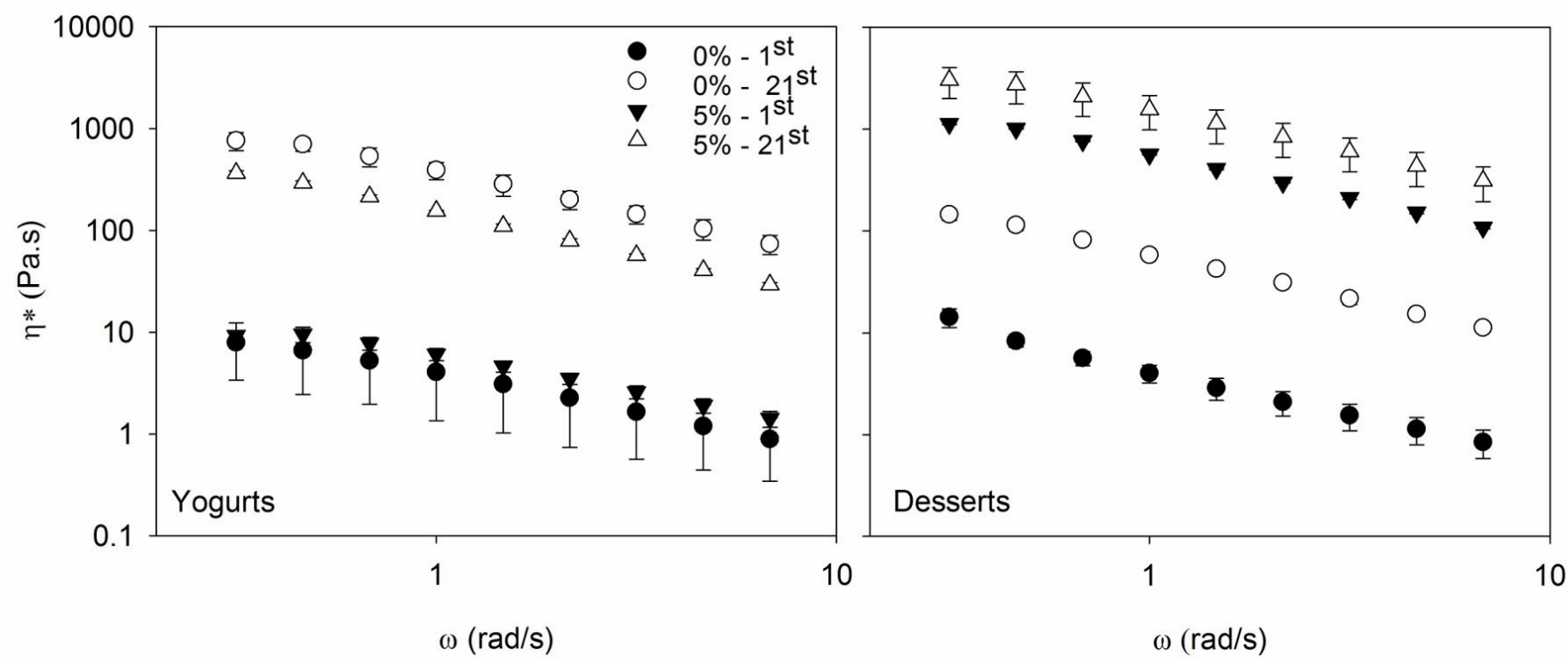

Figure 3. Complex viscosity $\left(\eta^{*}\right)$ of LWPC yogurts and desserts with $0 \%$ of SMP incorporation at the $1^{\text {st }}(\bullet)$ and $21^{\text {st }}$ day $(0)$ of storage, and with $5 \%$ of SMP incorporation at the $1^{\text {st }}(\boldsymbol{\nabla})$ and $21^{\text {st }}$ day $(\Delta)$ of storage.

protein polymerization and molecular structure rearrangements continue to occur during refrigeration, thus making the gels stronger, as also noted by other authors (Morr \& Ha, 1993; Rabiey \& Britten, 2009). In yogurts no significant differences were observed between products one day after production, with or without SMP fortification. However, at the end of the storage period the yogurts with SMP had lower $G$ ' and $G$ "values when compared to the ones without SMP addition. Once again, the presence of casein micelles that were not denatured in the presence of whey proteins increased protein heterogeneity and disturbed the protein network originating weaker gels. In the case of desserts, a very stable product was obtained using SMP (Figure 2). These results corroborate the higher WRC (Table 2) and hardness values (Table 3 ) achieved for these gels, indicating that the incorporation of 5\% SMP allowed for the production of stronger gel structures immediately after production when the whey proteins and caseins simultaneously undergo denaturation. Lee \& Lucey (2010) compared acid gels made from unheated milk with gels made from heat treated milk (at $\geq 78^{\circ} \mathrm{C}$ for $30 \mathrm{~min}$ ) and found higher $G^{\prime}$ values for the latter due to the increase in the covalent cross-linking of proteins after denaturation. In desserts produced from whey proteins only ( $0 \% \mathrm{SMP})$, an increase in $G$ ' and G" was observed over time. However, in this case the final values for $G$ ' and $G$ " after 21 days of storage were lower than those obtained for the yogurts, which is also confirmed by the lower viscosity values (Figure 3 ).

The mechanisms underlying thermal denaturation and aggregation of whey proteins have been extensively reviewed recently (Nicolai \& Durand, 2013; Wijayanti et al., 2014). It has been noted that the rate of protein thermal denaturation influences gel rheological characteristics. In general, firmer gels are produced when the velocity of thermal denaturation is lower, and proteins have enough time to react with each other and establish a well-ordered network (Damodaran, 1996; Singh, 2002). The thermal treatment in dessert type acid gels follows these assumptions (Figure 1), since it occurs over $30 \mathrm{~min}$ in glass cups that have a higher heat capacity and may promote slow heat transfer. In the case of the yogurt type acid gels, the thermal treatment is rapid (5 $\mathrm{min}$ ) and the proteins do not have enough time to rearrange, thus leading to weaker structures. Other authors (Dannenberg \& Kessler, 1988; Sodini et al., 2006) have also stated that the extent of whey protein denaturation during heat treatment affects functionality in terms of the viscosity of acid milk gels. From our results, in the case of SMP incorporation, it was observed that the more intense the heat treatment was (in the case of desserts), the higher the complex viscosity $\left(\eta^{*}\right)$ values were. Without the presence of caseins ( $0 \%$ SMP) the viscosity of the desserts was in the same range of magnitude as the yogurt viscosity, which may indicate that under these conditions the heat treatment does not seem to have a strong influence. Over time, the viscosity of the samples increased, although for yogurts with or without SMP did not vary as greatly, as it did in the case of desserts.

Further work should be focused on the evaluation of the sensory characteristics of the dairy products resulting from the utilization of LWPC. Since several formulations can result from the utilization of such ingredient, the sensory evaluation tests are crucial for the development and market launching of the novel products. The tests may be descriptive, making use of trained panels, but acceptance tests with consumers or even projective tests are important for the purpose (Janiaski et al., 2016; Esmerino et al., 2017a, b; Pinto et al., 2018).

\section{Conclusions}

LWPC is a suitable primary raw material for producing acid-induced gels. Food characteristics, such as flavour, colour, texture, rheological behaviour, may benefit of the properties of LWPC, particularly in the case of heat sensitive foods that may be subjected to non-thermal gelation methods. Colour was 
clearly affected in the case of dessert type products due to the intense heat treatment applied in this case. The acid-induced gels produced by lactic acid bacteria were weaker than the ones chemically acidified by GDL. Cold storage and fortification of acid gels with SMP improved the rheological properties, $G^{\prime}, G^{\prime \prime}$ and viscosity.

It can be concluded that the use of liquid whey proteins concentrates, achieved with less production costs then dehydrated products (WPC and WPI), allows for the production of high value and highly nutritional dairy products. LWPC are also suitable for incorporation in other food products. The use of more than one gelation method is another useful feature of these products, helping the food industry to meet consumer's demand.

\section{Acknowledgements}

This work is supported by national funds through the ministry of Agriculture and Rural Development and co-financed by the European Agricultural Fund for Rural Development (EAFRD), through the partnership agreement Portugal2020-PDR, under the project PDR2020-101-030768: LACTIES - Inovação, Eco-eficiência e Segurança em PME's do sector dos Lacticínios.

\section{References}

Amaral, G. V., Silva, E. K., Costa, A. L. R., Alvarenga, V. O., Cavalcanti, R. N., Esmerino, E. A., Guimarães, J. T., Freitas, M. Q., Sant'Ana, A. S., Cunha, R. L., Moraes, J., Silva, M. C., Meireles, M. A. A., \& Cruz, A. G. (2018). Whey-grape juice drink processed by supercritical carbon dioxide technology: Physical properties and sensory acceptance. Lebensmittel-Wissenschaft + Technologie, 92, 80-86. http://dx.doi. org/10.1016/j.lwt.2018.02.005.

Amatayakul, T., Sherkat, F., \& Shah, N. P. (2006). Syneresis in set yogurt as affected by EPS starter cultures and levels of solids. International Journal of Dairy Technology, 59(3), 216-221. http:// dx.doi.org/10.1111/j.1471-0307.2006.00264.x.

And, J. L., \& Guo, M. (2006). Effects of polymerized whey proteins on consistency and water holding properties of probiotic goat's milk yogurt. Journal of Food Science, 71(1), C34-C38. http://dx.doi. org/10.1111/j.1365-2621.2006.tb12385.x.

Association of Official Analytical Chemists - AOAC. (1980). Official methods of analysis (13rd ed., Method 16.032) Washington: AOAC.

Association of Official Analytical Chemists - AOAC. (1995). Official methods of analysis (13rd ed., Method 930.30) Washington: AOAC.

Aziznia, S., Khosrowshahi, A., Madadlou, A., \& Rahimi, J. (2008). Whey protein concentrate and gum tragacanth as fat replacers in nonfat yogurt: chemical, physical, and microstructural properties. Journal of Dairy Science, 91(7), 2545-2552. http://dx.doi.org/10.3168/ jds.2007-0875. PMid:18565911.

Bell, I. V. E. (1995). Preliminary studies on the gelation processes of fermented and GDL-acidified bovine and caprine milk systems. International Journal of Dairy Technology, 48(4), 112-116. http:// dx.doi.org/10.1111/j.1471-0307.1995.tb02479.x.

Bhullar, Y. S., Uddin, M. A., \& Shah, N. P. (2002). Effects of ingredients supplementation on textural characteristics and microstructure of yoghurt. Milchwissenschaft. Milk Science International, 57(6), 328-332.

Bryant, C. M., \& McClements, D. J. (1998). Molecular basis of protein functionality with special consideration of cold-set gels derived from heat-denatured whey. Trends in Food Science \& Technology, 9(4), 143-151. http://dx.doi.org/10.1016/S0924-2244(98)00031-4.
Bryant, C. M., \& McClements, D. J. (2000). Influence of $\mathrm{NaCl}$ and $\mathrm{CaCl} 2$ on cold-set gelation of heat-denatured whey protein. Journal of Food Science, 65(5), 801-804. http://dx.doi.org/10.1111/j.1365-2621.2000. tb13590.x.

Cavallieri, A. L. F., Costa-Netto, A. P., Menossi, M., \& Cunha, R. L. (2007). Whey protein interactions in acidic cold-set gels at different $\mathrm{pH}$ values. Le Lait, 87(6), 535-554. http://dx.doi.org/10.1051/lait:2007032.

Damodaran, D. G. (1996). Functional properties of proteins. In S. Nakai \& H. W. Modler (Eds.), Food proteins: properties and characterization. New York: VCH Publishers.

Dannenberg, F., \& Kessler, H. G. (1988). Effect of denaturation of $\beta$-lactoglobulin on texture properties of set-style nonfat yoghurt. 1. syneresis. Milchwissenschaft. Milk Science International, 43(10), 632-635.

Esmerino, E. A., Castura, J. C., Ferraz, J. P., Tavares Filho, E. R., Silva, R., Cruz, A. G., Freitas, M. Q., \& Bolini, H. M. A. (2017a). Dynamic profiling of different ready-to-drink fermented dairy products: A comparative study using Temporal Check-All-That-Apply (TCATA), Temporal Dominance of Sensations (TDS) and Progressive Profile (PP). Food Research International, 101, 249-258. http://dx.doi. org/10.1016/j.foodres.2017.09.012. PMid:28941691.

Esmerino, E. A., Tavares, E. R., Fo., Thomas Carr, B., Ferraz, J. P., Silva, H. L. A., Pinto, L. P. F., Freitas, M. Q., Cruz, A. G., \& Bolini, H. M. A. (2017b). Consumer-based product characterization using pivot profile, projective mapping and Check-all-that apply (CATA): a comparative case with Greek yogurt samples. Food Research International, 99(Pt 1), 375-384. http://dx.doi.org/10.1016/j. foodres.2017.06.001. PMid:28784495.

Faria, J. T., Minim, V. P. R., \& Minim, L. A. (2013). Evaluating the effect of protein composition on gelation and viscoelastic characteristics of acid-induced whey protein gels. Food Hydrocolloids, 32(1), 64-71. http://dx.doi.org/10.1016/j.foodhyd.2012.12.006.

Gauche, C. (2007). Polimerização de proteínas do soro de leite por transglutaminase e propriedades físicas de iogurte elaborado após tratamento enzimático (Tese de doutorado). Universidade Federal de Santa Catarina, Florianópolis.

Guimarães, J. T., Silva, E. K., Costa, A. L. R., Cunha, R. L., Freitas, M. Q., Meireles, M. A. A., \& Cruz, A. G. (2018). Manufacturing a prebiotic whey beverage exploring the influence of degree of inulin polymerization. Food Hydrocolloids, 77, 787-795. http://dx.doi. org/10.1016/j.foodhyd.2017.11.021.

Guimarães, J. T., Silva, E. K., Ranadheera, C. S., Moraes, J., Raices, R. S. L., Silva, M. C., Ferreira, M. S., Freitas, M. Q., Meireles, M. A. A., \& Cruz A. G. (2019). Effect of high-intensity ultrasound on the nutritional profile and volatile compounds of a prebiotic soursop whey beverage. Ultrasonics Sonochemistry, 55, 157-164. http://dx.doi. org/10.1016/j.ultsonch.2019.02.025.

Ha, E., \& Zemel, M. B. (2003). Functional properties of whey, whey components, and essential amino acids: mechanisms underlying health benefits for active people (review). The Journal of Nutritional Biochemistry, 14(5), 251-258. http://dx.doi.org/10.1016/S09552863(03)00030-5. PMid:12832028.

Henriques, M. H. F., Gomes, D. M. G. S., Pereira, C. J. D., \& Gil, M. H. M. (2012). Effects of liquid whey protein concentrate on functional and sensorial properties of set yoghurts and fresh cheese. Food and Bioprocess Technology, 6(4), 952-963. http://dx.doi.org/10.1007/ s11947-012-0778-9.

Henriques, M., Gomes, D., \& Pereira, C. (2017). Liquid whey protein concentrates produced by ultrafiltration as primary raw materials for thermal dairy gels. Food Technology and Biotechnology, 55(4), 454463. http://dx.doi.org/10.17113/ftb.55.04.17.5248. PMid:29540980. 
Henriques, M., Gomes, D., Rodrigues, D., Pereira, C., \& Gil, M. (2011). Performance of bovine and ovine liquid whey protein concentrate on functional properties of set yoghurts. Procedia Food Science, 1, 2007-2014. http://dx.doi.org/10.1016/j.profoo.2011.10.001.

Hong, Y.-H., \& Creamer, L. K. (2002). Changed protein structures of bovine [beta]-lactoglobulin B and [alpha]-lactalbumin as a consequence of heat treatment. International Dairy Journal, 12(4), 345-359. http://dx.doi.org/10.1016/S0958-6946(02)00030-4.

Instituto Português da Qualidade. (1982). Yogurt - acidity determination (NP Standard No. 701 in Portuguese). Monte de Caparica: IPQ.

Instituto Português da Qualidade. (1983). Milk-acidity determination (NP Standard No. 470 in Portuguese). Monte de Caparica: IPQ.

Instituto Português da Qualidade. (1987). Yogurt - fat content determination, gerber method (NP Standard No. 1923 in Portuguese). Monte de Caparica: IPQ.

Instituto Português da Qualidade. (2002). Milk - fat content determination, gerber method (NP Standard No. 469 in Portuguese). Monte de Caparica: IPQ.

International Organization for Standardization - ISO. (2001). Milk - determination of nitrogen content - Part 1: Kjeldahl method (ISO Standard No. 8968-1). London: ISO.

Janiaski, D. R., Pimentel, T. C., Cruz, A. G., \& Prudêncio, S. H. (2016). Strawberry-flavored yogurts and whey beverages: what is the sensory profile of the ideal product? Journal of Dairy Science, 99(7), 52735283. http://dx.doi.org/10.3168/jds.2015-10097. PMid:27157581.

Lee, W. J., \& Lucey, J. A. (2010). Formation and physical properties of yogurt. Asian-Australasian Journal of Animal Sciences, 23(9), 11271136. http://dx.doi.org/10.5713/ajas.2010.r.05.

Lucey, J. A., Munro, P. A., \& Singh, H. (1999). Effects of heat treatment and whey protein addition on the rheological properties and structure of acid skim milk gels. International Dairy Journal, 9(3-6), 275-279. http://dx.doi.org/10.1016/S0958-6946(99)00074-6.

Martín-Diana, A. B., Janer, C., Peláez, C., \& Requena, T. (2004). Effect of milk fat replacement by polyunsaturated fatty acids on the microbiological, rheological and sensorial properties of fermented milks. Journal of the Science of Food and Agriculture, 84(12), 15991605. http://dx.doi.org/10.1002/jsfa.1844.

Morr, C. V., \& Ha, E. Y. W. (1993). Whey protein concentrates and isolates: processing and functional properties. Critical Reviews in Food Science and Nutrition, 33(6), 431-476. http://dx.doi. org/10.1080/10408399309527643. PMid:8216810.

Nicolai, T., \& Durand, D. (2013). Controlled food protein aggregation for new functionality. Current Opinion in Colloid \& Interface Science, 18(4), 249-256. http://dx.doi.org/10.1016/j.cocis.2013.03.001.

Patel, S. (2015). Functional food relevance of whey protein: a review of recent findings and scopes ahead. Journal of Functional Foods, 19(1), 308-319. http://dx.doi.org/10.1016/j.jff.2015.09.040.

Pereira, C. D., Henriques, M., Gomes, D., Gomez-Zavaglia, A., \& de Antoni, G. (2015). Novel functional whey-based drinks with great potential to the dairy industry. Food Technology and Biotechnology, 53(3), 307-314. http://dx.doi.org/10.17113/ftb.53.03.15.4043. PMid:27904362.

Phadungath, C. (2010). Basic measurement for food texture. Texture Technologies Corp - Texture Profile Analysis. Retrieved from http:// www.texturetechnologies.com/texture_profile_analysis.html

Pinto, L. P. F., Silva, H. L. A., Kuriya, S. P., Maçaira, P. M., Cyrino Oliveira, F. L., Cruz, A. G., Esmerino, E. A., \& Freitas, M. Q. (2018). Understanding perceptions and beliefs about different types of fermented milks through the application of projective techniques: a case study using Haire's shopping list and free word association. Journal of Sensory Studies, 33(3), e12326. http://dx.doi.org/10.1111/joss.12326.
Puvanenthiran, A., Williams, R. P. W., \& Augustin, M. A. (2002). Structure and visco-elastic properties of set yoghurt with altered casein to whey protein ratios. International Dairy Journal, 12(4), 383-391. http://dx.doi.org/10.1016/S0958-6946(02)00033-X.

Rabiey, L., \& Britten, M. (2009). Effect of protein composition on the rheological properties of acid-induced whey protein gels. Food Hydrocolloids, 23(3), 973-979. http://dx.doi.org/10.1016/j. foodhyd.2008.07.009.

Sanmartín, B., Díaz, O., Rodríguez-Turienzo, L., \& Cobos, A. (2015). Properties of Heat-induced gels of caprine whey protein concentrates obtained from clarified cheese whey. Small Ruminant Research, 123(1), 142-148. http://dx.doi.org/10.1016/j.smallrumres.2014.10.014.

Singh, H. (2002). Milk proteins - functional properties. In H. Roginski, J. W. Fuquay \& P. F. Fox (Eds.), Encyclopaedia of dairy sciences. London: Academic Press.

Smithers, G. W. (2015). Whey-ing up the options-yesterday, today and tomorrow. International Dairy Journal, 48, 2-14. http://dx.doi. org/10.1016/j.idairyj.2015.01.011.

Sodini, I., Lucas, A., Oliveira, M. N., Remeuf, F., \& Corrieu, G. (2002). Effect of milk base and starter culture on acidification, texture, and probiotic cell counts in fermented milk processing. Journal of Dairy Science, 85(10), 2479-2488. http://dx.doi.org/10.3168/jds.S00220302(02)74330-0. PMid:12416799.

Sodini, I., Mattas, J., \& Tong, P. S. (2006). Influence of $\mathrm{pH}$ and heat treatment of whey on the functional properties of whey protein concentrates in yoghurt. International Dairy Journal, 16(12), 14641469. http://dx.doi.org/10.1016/j.idairyj.2005.03.014.

Sodini, I., Remeuf, F., Haddad, S., \& Corrieu, G. (2004). The relative effect of milk base, starter, and process on yogurt texture: a review. Critical Reviews in Food Science and Nutrition, 44(2), 113-137. http://dx.doi.org/10.1080/10408690490424793. PMid:15116758.

Tamime, A. Y., \& Robinson, R. K. (2007). Yoghurt: science and technology. Cambridge: Woodhead Publishing Limited.

Torres, I. C., Mutaf, G., Larsen, F. H., \& Ipsen, R. (2016). Effect of hydration of microparticulated whey protein ingredients on their gelling behaviour in a non-fat milk system. Journal of Food Engineering, 184, 31-37. http://dx.doi.org/10.1016/j.jfoodeng.2016.03.018.

Totosaus, A., Montejano, J. G., Salazar, J. A., \& Guerrero, I. (2002). A review of physical and chemical protein-gel induction. International Journal of Food Science \& Technology, 37(6), 589-601. http://dx.doi. org/10.1046/j.1365-2621.2002.00623.x.

Vargas, M., Pastor, C., Chiralt, A., McClements, D. J., \& González-Martínez, C. (2008). Recent advances in edible coatings for fresh and minimally processed fruits. Critical Reviews in Food Science and Nutrition, 48(6), 496-511. http://dx.doi.org/10.1080/10408390701537344. PMid:18568856.

Wijayanti, H. B., Bansal, N., \& Deeth, H. C. (2014). Stability of whey proteins during thermal processing: a review. Comprehensive Reviews in Food Science and Food Safety, 13(6), 1235-1251. http://dx.doi. org/10.1111/1541-4337.12105.

Yadav, J. S. S., Yan, S., Pilli, S., Kumar, L., Tyagi, R. D., \& Surampalli, R. Y. (2015). Cheese whey: a potential resource to transform into bioprotein, functional/nutritional proteins and bioactive peptides. Biotechnology Advances, 33(6), 756-774. http://dx.doi.org/10.1016/j. biotechadv.2015.07.002. PMid:26165970.

Zhang, S., Hsieh, F. H., \& Vardhanabhuti, B. (2014). Acid-induced gelation propertien of heated whey protein-pectin soluble complex (Part I): effect of initial pH. Food Hydrocolloids, 36, 76-84. http:// dx.doi.org/10.1016/j.foodhyd.2013.07.029. 